\title{
Protective Role of Putrescine against Picloram Induced Genomic Instability and DNA Methylation in Phaseolus vulgaris
}

\author{
Mahmut Sinan TAȘPINAR ${ }^{1}$, Esra ARSLAN ${ }^{2}$, Murat AYDIN ${ }^{1}$, Burcu SIĞMAZ ${ }^{3}$, Güleray AĞAR²
}

\begin{abstract}
Picloram (4-amino-3-5-6-trichloropicolinic acid) is an important synthetic auxin and it is one of the most widely used herbicides in agriculture. The use of picloram is representing a potential hazardous to ecosystems and the human health. Putrescine is a kind of polyamine which has a role in plant metabolism such as protecting membrane stability, removing free radicals and nucleic acid and protein synthesis, etc. In this study, DNA damage levels in Phaseolus vulgaris treated with picloram, DNA methylation changes and whether putrescine was any alleviative impact on these alterations were investigated. DNA methylation pattern changes and DNA damage levels were determined by using Randomly Amplified Polymorphic DNA (RAPDs) and Coupled Restriction Enzyme Digestion-Random Amplification (CRED-RAs), respectively. The obtained results indicated that all doses of picloram $\left(5,10,20\right.$ and $\left.40 \mathrm{mg} \mathrm{L}^{-1}\right)$ had a negative effect on RAPDs profile changes (increased DNA damage levels) and decreased of Genomic Template Stability (GTS) and also DNA hypomethylation was seen. However, all concentrations of putrescine $(0.01,0.1$ and $1 \mathrm{ppm})$ reduced these harmful effects of picloram. Consequently, putrescine can be an alternative for reducing genotoxic damage against chemical mutagens in plants.
\end{abstract}

Keywords: DNA methylation, genomic instability, picloram, putrescine

\section{Phaseolus vulgaris'te Genomik Kararsızlı ve DNA Metilasyonunu İndükleyen Piklorama karşı Putresinin Koruyucu Rolü}

ÖZET: Pikloram (4-amino-3-5-6-trikloropikolinik asit) önemli bir sentetik oksin olup, tarımda en çok kullanılan herbisitlerden biridir. Pikloram kullanımı, ekosistem ve insan sağlığ için potansiyel bir tehlike oluşturmaktadır. Bir poliamin çeşidi olan putresinin bitki metabolizmasında; membran stabilitesinin korunması, serbest radikallerin uzaklaştırılması ve nükleik asit ve protein sentezi gibi rolü vardır. Bu çalışma, pikloram uygulanan Phaseolus vulgaris' teki DNA hasar düzeyleri ve DNA metilasyon değişiklikleri ile putresinin bu değişimler üzerinde koruyucu etkisinin olup olmadığının belirlenmesini amaçlamıştır. DNA hasar düzeylerini ve DNA metilasyon değişimlerini belirlemek için Rastgele Çoğaltılmış Polimorfik DNA (RAPD) ve Çift Restriksiyon Enzim KesimiRastgele Çoğaltım (CRED-RA) kullanılmıştır. Sonuçlar, tüm pikloram dozlarıın $\left(5,10,20\right.$ ve $\left.40 \mathrm{mg} \mathrm{L}^{-1}\right)$ RAPD profil değişikliklerini (DNA hasarının) artırdığını ve Genomik Kararılıı Stabilitesini (GTS) azalttığını ve ayrıca DNA hipometilasyonunun oluştuğunu göstermiştir. Bununla birlikte, kullanılan tüm putresin konsantrasyonları (0.01, 0.1 ve $1 \mathrm{ppm})$ putresinin bu zararlı etkilerini azaltmıştır. Sonuç olarak, putresin, bitkilerdeki kimyasal mutajenlere karşı genotoksik hasarı azaltmak için bir alternatif olabilir.

Anahtar kelimeler: DNA metilasyonu, genomik kararsızlık, pikloram, putresin

\footnotetext{
Mahmut Sinan TAŞPINAR (0000-0001-6399-2703), Murat AYDIN (0000-0003-1091-0609), Atatürk Üniversitesi Tarımsal Biyoteknoloji Bölümü, Erzurum, Türkiye

Esra ARSLAN(0000-0002-9062-6896), Güleray AĞAR(0000-0002-8445-5082), Atatürk Üniversitesi Biyoloji Bölümü, Erzurum, Türkiye Burcu SIĞMAZ(0000-0001-7411-9440), Atatürk Üniversitesi Tarla Bitkileri Bölümü, Erzurum, Türkiye
}

Sorumlu yazar/Corresponding Author: Murat AYDIN,maydin@atauni.edu.tr 


\section{INTRODUCTION}

Picloram is an important synthetic auxin that was used often as a supplement in plant cell culture media such as Murashige and Skoog's (MS) in the plant research laboratories. It was also used to prevent unwanted and invasive broadleaf weeds present in fields. However, picloram is highly toxic to many nontarget plants that were grown nearby plants through the roots in soil. Moreover, irrigation water is polluted with picloram application into rangeland, pastures and forests and may be hazardous to endangered plants. Studies indicated that picloram caused increasing viscosity of the cytoplasm in leaf tissue and in stamen hairs, necrosis, destroying of nuclear structure, mitosis decreasing, micronucleus increasing, pink mutation and chromosomal aberration in higher plants (Mohammed and Ma, 1999; Olea-Popelka et al., 2005). It was determined to be a teratogen, carcinogen, potent mutagen and also reproductive effects in several species of experimental animals were identified (Oakes et al., 2002). Recently, several studies have demonstrated that the some herbicides such as 2,4-dichlorophenoxyacetic acid lead to alteration of gene expression levels of some genes through DNA methylation (Leljak-Levanic et al., 2004). Temel and Gozukirmizi (2013) reported that dicamba caused increasing in cytosine methylation and changed in retro element movements in barley callus culture. Plants may be followed different ways in order to protect from stress; resistance, tolerance and avoidance. These strategies effect somatic growth (Sung and Amasino, 2004), heritable, modifications of gene expression known as epigenetic and abscisic acid (ABA), salicylic acid and polyamine levels (Grativol et al., 2012). Especially, polyamines such as putrescine, spermidine, spermine may establish a correlation with proteins, nucleic acids, membrane phospholipids and cell wall constitutents. Numerous studies claim that polyamines bound to guard DNA from enzymatic degradation, mechanical shearing and X-ray irradiation and also stabilize RNA to counteract of ribosomal dispersion (Miyamoto et al., 1993; Ruiz-Herrera et al., 1995). Additionally, some researchers also suggested that polyamines have ability to protect replicating DNA from oxidative damages (Khan et al., 1992; Miyamoto et al., 1993; D'Agustino et al., 2005). It was first reported that polyamines had the role of selective inhibition cytosine- DNA methylases by prevent both the binding and activity of these enzymes (Ruiz-Herrera et al., 1995). Although we have a lot of knowledge about the effects of picloram on non-target organisms, there is no report shown the effect of picloram on DNA methylation and DNA damage (by using the RAPD technique). Thus, the goal of this study was to explain DNA methylation changes and genotoxic potential of the picloram on bean seedlings and discuss if putrescine has any effect on these parameters.

\section{MATERIALS AND METHODS}

\section{Plant Growth and Treatment Conditions}

Phaseolus vulgaris L. cv. Elkoca seeds were obtained from Department of Field Crops, Faculty of Agriculture, Ataturk University, Erzurum, Turkey. Firstly, sterilization was made with in $0.5 \%$ sodium hypochlorite $(\mathrm{NaOCl})$ solution for $10 \mathrm{~min}$, after sterile water was used for rinse the seeds. 25 seeds were put in each plastic box which included two layers of filter paper moistened with $25 \mathrm{ml}$ distilled water. $25 \pm$ $1^{\circ} \mathrm{C}$ and dark conditions were provided until primary roots were grown at $0.5-1 \mathrm{~cm}$ length. Then, different concentrations of picloram $\left(5,10,20\right.$ and $\left.40 \mathrm{mg} \mathrm{L}^{-1}\right)$ and putrescine $(0.01,0.1$ and $1 \mathrm{ppm})$ solutions were exposed to bean seedlings for $8 \mathrm{~h}$ (Zeid and Shedeed, 2006). Treated seedlings were grown in pots of a peat/soil mix (5 plants/pot) at $25 \pm 1^{\circ} \mathrm{C}$ with a $16 \mathrm{~h}$ photoperiod of 60 $\mu \mathrm{mol}$ photons $/ \mathrm{m}^{2} \mathrm{~s}$ provided by white fluorescent lamp, at a relative humidity of $70-75 \%$ in a growth chamber (Sanyo Model, MIR 253, Sanyo Electric Biomedical Co. Ltd., Japan). 3 replicates were made. Bulk leaves were randomly collected from ten plants for each treatment after emergence of leaf 3 (leaves numbered from base) and immediately taken in $-80^{\circ} \mathrm{C}$.

\section{Genomic DNA Isolation, RAPDs and CRED- RAs Procedures and PCR Methods}

CTAB method (Taspinar et al., 2009) was used for genomic DNA (gDNA) isolation. RAPD-PCR was used for determining the genetic damage. 32 RAPD primers (Operon Technologies Inc., Alameda, CA, USA) were tested with bulked DNA of control treatment $(0 \mathrm{mg}$ $\mathrm{L}^{-1}$ picloram $+0 \mathrm{ppm}$ putrescine). Only 14 primers were used in RAPD-PCR reactions due to amplified polymorphic amplicons and 8 primers were selected for CRED-RA PCR reactions according to have most polymorphic bands from RAPD primers (Table 1). 
Table 1. The primer sequences used for RAPD and CRED-RA analysis

\begin{tabular}{cc}
\hline Primer Name & Sequence (5'-3') \\
\hline OPW-20 & TGTGGCAGCA \\
OPA-4 & AATCGGGCTG \\
OPW-13 & CACAGCGACA \\
OPA-1 & CAGGCCCTTC \\
OPH-18 & GAATCGGCCA \\
OPH-19 & CTGACCAGCC \\
OPY-8 & AGGCAGAGCA \\
OPW-17 & GTCCTGGGTT \\
OPY-11 & AGACGATGGG \\
OPY-13 & GGGTCTCGGT \\
OPY-15 & AGTCGCCCTT \\
OPW-4 & CAGAAGCGGA \\
OPY-16 & GGGCCAATGT \\
OPH-16 & TCTCAGCTGG \\
\hline
\end{tabular}

RAPD-PCR reaction mix contents and conditions were given in Table 2.

Table 2. PCR reaction mix contents and conditions

\begin{tabular}{ll}
\hline & PCR Reaction Mix Contents \\
\hline PCR buffer & $1 \mathrm{X}$ \\
\hline $\mathrm{MgCl}_{2}$ & $2.5 \mathrm{mM}$ \\
\hline dNTP & $400 \mu \mathrm{M}$ \\
\hline gDNA & $50 \mathrm{ng}$ \\
\hline Primer & $10 \mathrm{pmol}$ \\
\hline Taq DNA polymerase & $1 \mathrm{U}$ \\
\hline Total volume of each sample & $20 \mu \mathrm{M}$ \\
\hline
\end{tabular}

\section{PCR Conditions}

RAPD: 1 cycle at $95^{\circ} \mathrm{C}$ for $5 \mathrm{~min}, 42$ cycles of $\left(94^{\circ} \mathrm{C}\right.$ for $1 \mathrm{~min}, 36^{\circ} \mathrm{C}$ for $1 \mathrm{~min}$ and $72^{\circ} \mathrm{C}$ for $\left.2 \mathrm{~min}\right), 1$ cycle at $72^{\circ} \mathrm{C}$ for $15 \mathrm{~min}$ CRED-RA: 1 cycle at $95^{\circ} \mathrm{C}$ for $5 \mathrm{~min}, 38$ cycles of $\left(94^{\circ} \mathrm{C}\right.$ for $1 \mathrm{~min}, 36^{\circ} \mathrm{C}$ for $1 \mathrm{~min}$ and $72^{\circ} \mathrm{C}$ for $\left.2 \mathrm{~min}\right), 1 \mathrm{cycle}$ at $72^{\circ} \mathrm{C}$ for $15 \mathrm{~min}$.

There is a significant difference in CRED-RAPCR reaction mix that gDNA samples from each treatment were separately digested with HpaII (New England Biolabs, Beijing, China, \#R0171) and MspI (New England Biolabs, Beijing, China, \#R0106) endonucleases according to manufacturers's instructions (which cut the sequence 5'-C/CGG-3'with different sensitivity to cytosine methylation; MspI cuts if the inner $\mathrm{C}$ is methylated, whereas HpaII cannot cleave in the presence of methyl groups). So, $50 \mathrm{ng}$ digested 
DNA (for each endonuclease) samples were added in PCR mix instead of non-digested gDNA.

\section{Electrophoresis}

RAPDs and CRED-RAs amplification products were resolved on $1 \%$ agarose gel ( $0.5 \mathrm{X}$ TBE buffer, $80 \mathrm{~V}$ for $150 \mathrm{~min}$ ). Gels dyed with ethidium bromide displayed under UV light and photographed by gel visualization system (DNR MiniBis $16 \mathrm{~mm}$ pro). DNA ladder (50-10 000 bp, Sigma-D7058) was used for estimation of the sizes of fragments.

\section{Analysis}

Total Lab TL120 computer software was used for evaluating of RAPD patterns. Genomic Template Stability (GTS, \%) was calculated as follows: $\mathrm{GTS}=100-(100 \mathrm{x} a / n)$. The average number of polymorphisms (\%) was calculated for each dose to realize CRED-RA analysis. To calculate the number of polymorphisms $(\%)$, the following formula was used $100 \mathrm{x} a / n$ (Yildirim et al., 2014).

\section{RESULTS AND DISCUSSION}

Picloram is an important synthetic auxin and is used in agriculture as a herbicide to control a wide range of agricultural and horticultural crops with many annual weeds and broad-leaved weeds. Picloram is highly toxic to many non-target plants. Furthermore, irrigation water contaminated with picloram can damage or kill crop plants. In fact, picloram applied to pastures, rangeland, or forests may be hazardous to endangered plants. This study evaluated the genotoxic effects of picloram by using RAPD technique. In RAPD analysis, a set of 32 different synthetic oligonucleotids were tested with control DNA sample and 14 out of these were resulted specific and stable DNA profiles in Phaseolus vulgaris genome. The treated plant samples (picloram and/or putrescine) showed significant differences according to the untreated samples. These differences were showed as variation in band intensity, loss of normal bands or appearance of new polymorphic bands. Each primer produced a band gap of 3-9 with an average of 4.85 bands per primer. According to the obtained results; amplified bands were ranged from 412 (OPY-15) to 3205 (OPY-16). The molecular sizes of bands that gained or lost among the control and treatment groups were given in Table 3 . Changes in RAPD profiles were measured as GTS (a qualitative measurement reflects changes in RAPD patterns) as regards the pattern showed in the control treatment. Increased picloram concentration caused decreasing GTS value. The highest GTS value $(60.9 \%)$ was observed in $5 \mathrm{mg} \mathrm{L}^{-1}$ picloram treatment, while the lowest GTS value that shown harmful effects of picloram (46.6\%) was observed in $40 \mathrm{mg} \mathrm{L}^{-1}$ picloram treatment. However, increased putrescine concentration caused increasing GTS value in picloram exposed plants.

The high level putrescine dose (1 ppm) was found to be the best dose for GTS $(87.5 \%)$ in both picloram treated and putrescine untreated plants. Our conclusions are consistent with the previously demonstrated genotoxic effect of picloram with various mutagenens tests in plants (Mohammed and Ma, 1999; Salvi et al., 2001; Correia et al., 2011). Sawamura and Jackson, (1968) have reported that picloram decreased the rate of cytoplasm streaming in stamen hairs of Tradescantia, while Brownian movement increased and numerous and size of chloroplasts affected in Vicia leaf.

Although the DNA damage mechanism of picloram is not illuminated yet, previous researches indicated that acidic herbicides such as 2,4-D can stimulate the release of free radicals, including reactive oxygen species with oxidative DNA damage (Balague et al., 2001; Duchnowicz and Koter, 2003). Moreover, there is no study on the role of picloram on DNA methylation changes in putrescine-exposed plants. In our previous study, we determined the effect of picloram on DNA methylation in somaclonal variation conditions (Aydin et al., 2016). This paper aims indicating DNA methylation changes that emerged picloram and putrescine interactions in bean. The obtained results demonsrated that picloram caused DNA hypomethylation. 












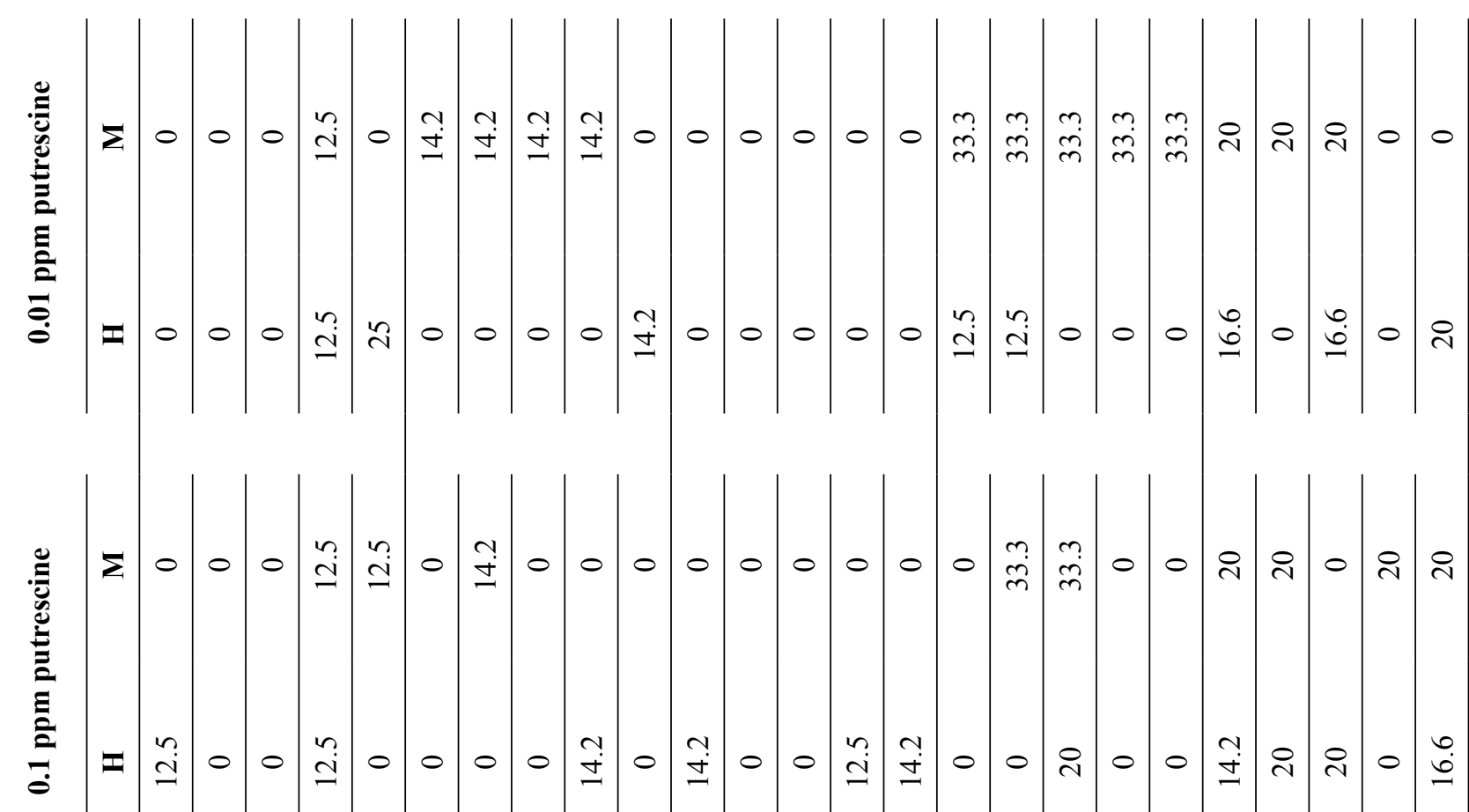

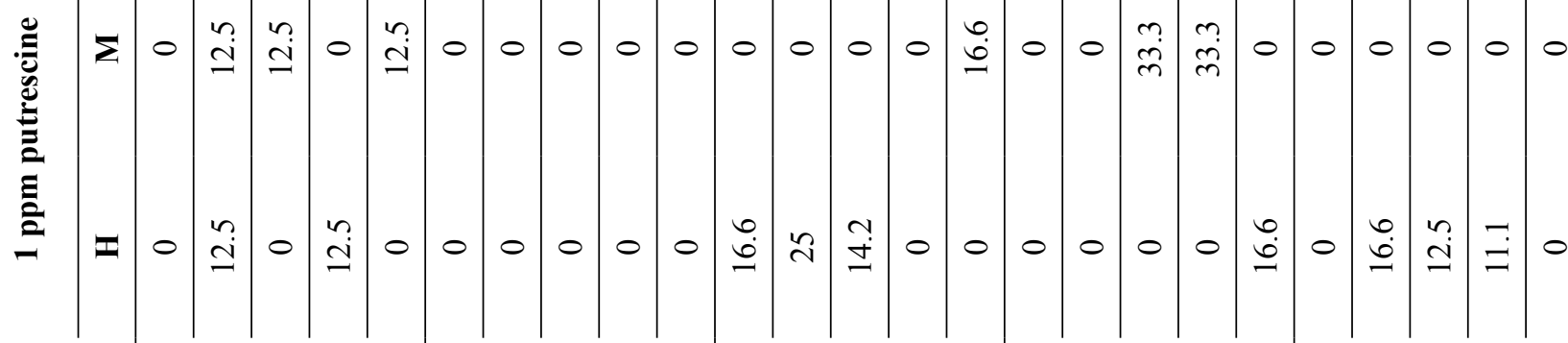

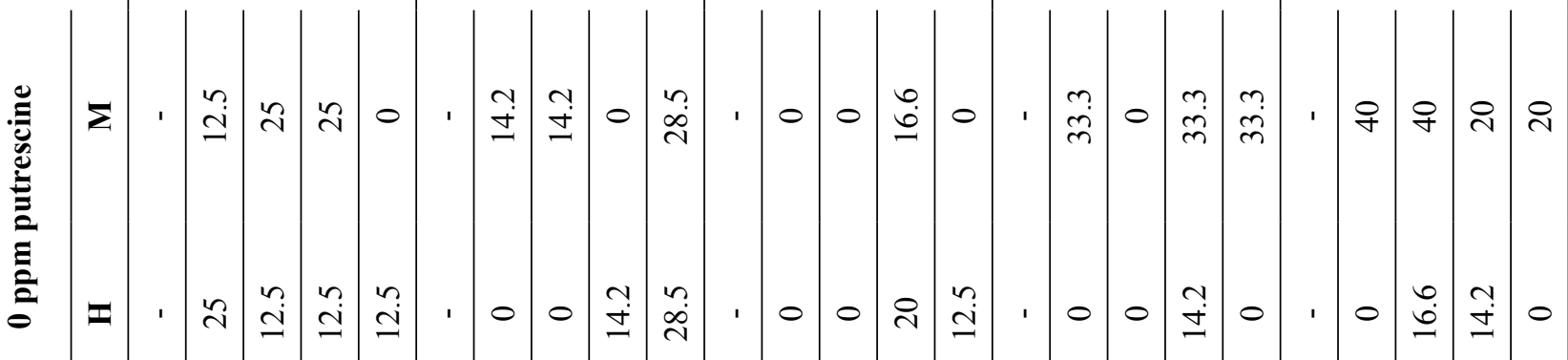

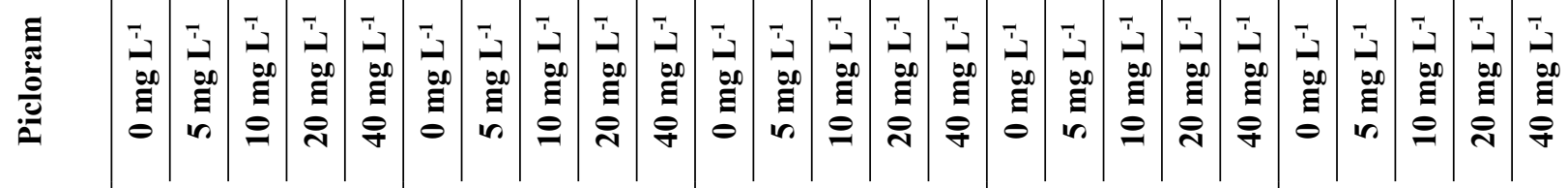
竞

$\frac{m}{\frac{1}{2}}$

$\frac{7}{3}$

$\underset{1}{\stackrel{1}{c}}$

$\frac{\infty}{\frac{1}{1}}$ 
Table 4 (Continue). CRED-RA band amounts and polymorphism \%

\begin{tabular}{|c|c|c|c|c|c|c|c|c|c|}
\hline \multirow{5}{*}{ OPY-16 } & $0 \mathrm{mg} \mathrm{L}^{-1}$ & - & - & 12.5 & 16.6 & 20 & 16.6 & 0 & 16.6 \\
\hline & $5 \mathrm{mg} \mathrm{L}^{-1}$ & 0 & 0 & 0 & 16.6 & 0 & 16.6 & 14.2 & 16.6 \\
\hline & $\begin{array}{c}10 \mathrm{mg} \\
\mathbf{L}^{-1}\end{array}$ & 0 & 33.3 & 0 & 0 & 0 & 16.6 & 0 & 16.6 \\
\hline & $\begin{array}{c}20 \mathrm{mg} \\
\mathbf{L}^{-1}\end{array}$ & 16,6 & 16.6 & 0 & 0 & 33.3 & 16.6 & 25 & 16.6 \\
\hline & $\begin{array}{c}40 \mathrm{mg} \\
\mathrm{L}^{-1}\end{array}$ & 0 & 16.6 & 0 & 0 & 14.2 & 16.6 & 0 & 16.6 \\
\hline \multirow{5}{*}{ OPW-6 } & $0 \mathrm{mg} \mathrm{L}^{-1}$ & - & - & 0 & 0 & 0 & 0 & 0 & 0 \\
\hline & $5 \mathrm{mg} \mathrm{L}^{-1}$ & 20 & 20 & 0 & 0 & 20 & 0 & 0 & 0 \\
\hline & $\begin{array}{c}10 \mathrm{mg} \\
\mathbf{L}^{-1}\end{array}$ & 25 & 20 & 0 & 0 & 0 & 0 & 0 & 0 \\
\hline & $20 \mathrm{mg}$ & 0 & 0 & 16.6 & 0 & 16.6 & 0 & 0 & 20 \\
\hline & $\begin{array}{c}40 \mathrm{mg} \\
\mathrm{L}^{-1}\end{array}$ & 16.6 & 0 & 0 & 0 & 0 & 0 & 0 & 20 \\
\hline \multirow{5}{*}{ Average } & $0 \mathrm{mg} \mathrm{L}^{-1}$ & - & - & 4.1 & 2.3 & 8.7 & 5.2 & 6.1 & 12.0 \\
\hline & $5 \mathrm{mg} \mathrm{L}^{-1}$ & 6.4 & 17.1 & 7.7 & 4.1 & 5.7 & 12.0 & 3.8 & 12.0 \\
\hline & $\begin{array}{c}10 \mathrm{mg} \\
\mathrm{L}^{-1}\end{array}$ & 7.7 & 14.7 & 3.8 & 6.5 & 5.7 & 7.1 & 2.3 & 11.7 \\
\hline & $\begin{array}{c}20 \mathrm{mg} \\
\mathrm{L}^{-1}\end{array}$ & 13.1 & 15.9 & 3.3 & 4.7 & 12.7 & 7.0 & 5.3 & 10.9 \\
\hline & $\begin{array}{c}40 \mathrm{mg} \\
\mathrm{L}^{-1}\end{array}$ & 10.0 & 14.0 & 2.3 & 4.1 & 6.4 & 7.0 & 8.4 & 9.9 \\
\hline
\end{tabular}

H:Hpa II, M: Msp I

Seven primers used for RAPD-PCR amplification produced specific and stable amplicons in CRED-

RAs analysis. Compared with the PCR products obtained from the control DNA, picloram and/or putrescine treatments showed changes in CRED-RA patterns (Table 4). DNA hypomethylation occurred and its value increased depending on the decrease in picloram concentration. However, putrescine led to a reduction in picloram-induced DNA methylation. DNA methylation values were $14.0 \%$ in $40 \mathrm{mg} \mathrm{L}^{-1}$ picloram exposed plant whereas this value was determined as $4.1 \%$ in $40 \mathrm{mg} \mathrm{L}^{-1}$ picloram and $1 \mathrm{mM}$ putrescine treated plant (Table 4).

With an increase in the dose of putrescine, DNA methylation values of picloram treated plants were decreased. The results indicated that putrescine had the antagonistic effect against picloram. Recently, several studies have indicated that stress positively contributed to tolerance as alter genes expression by DNA methylation and histone modifications
(Wang et al., 2016; Feng et al., 2016). In additional, the present study evaluated the protective role of putrescine against picloram genotoxicity. Our results showed that putrescine treatment caused amelioration effect against DNA hypomethylation and DNA damage that was caused by picloram.

Previous research have revealed that polyamines guard DNA from enzymatic degradation, X-ray irradiation and also stabilize RNA, to counteract of ribosomal dispersion (Miyamoto et al., 1993; RuizHerrera et al., 1995). Additionally, some researchers also suggested that polyamines have ability to protect replicating DNA from oxidative damages as well as DNA and RNA biosynthesis stimulate (Khan et al., 1992; Miyamoto et al., 1993; D’Agustino et al., 2005). The protective effects of putrescine may relate to positive charged properties. It has ability to binding minor groove of B-DNA, moving to the 
major groove of A-DNA. Also, these studies have been proposed that positive charged polyamines bind to the minor groove of B-DNA, moving to the major groove in the A form. This paper is the first report that showed the effect of treatment with different concentrations of picloram and putrescine on DNA methylation. DNA methylation changes induced by putrescine may affect some specific genes activation to increase plant resistance under stress conditions.

\section{REFERENCES}

Aydin M, Arslan E, Taspinar MS, Karadayi G, Agar G, 2016. Analyses of somaclonal variation in endosperm-supported mature embryo culture of rye (Secale cereale L.). Biotechnology and Biotechnological Equipment, 30: 1082-1089.

Balague C, Sturtz N, Duffard R, Evangelista de Duffard AM, 2001. Effect of 2,4- dichlorophenoxyacetic acid herbicide on Escherichia coli growth, chemical composition, and cellular envelope. Environmental Toxicology, 16: 43-53.

Correia S, Lopes ML, Canhoto JM, 2011. Somatic embryogenesis induction system for cloning an adult Cyphomandra betacea (Cav.) Sendt. (tamarillo). Trees, 25: 1009-1020.

D'Agostino L, Di Pietro M, Di Luccia A, 2005. Nuclear aggregates of polyamines are supramolecular structures that play a crucial role in genomic DNA protection and conformation. FEBS Journal, 272: $3777-3787$.

Duchnowicz P, Koter M, 2003. Damage to the erythrocyte membrane caused by chlorophenoxyacetic herbicides. Cellular and Molecular Biology Letters, 8: 25-30.

Feng SJ, Liu XS, Tao H, Tan SK, Chu SS, Oono Y, Zhang XD, Chen J, Yang ZM, 2016. Variation of DNA methylation patterns associated with gene expression in rice (Oryza sativa) exposed to cadmium. Plant Cell and Environment, 39: 2629-2649.

Grativol C, Hemerly AS, Ferreira PCG, 2012. Genetic and epigenetic regulation of stress responses in natural plant populations. Biochimica et Biophysica Acta, 1819: 176-185.

Khan AU, Di-Mascio P, Medeiros MHG, Wilson T, 1992. Spermine and spermidine protection of plasmid DNA against single-strand breaks induced by singlet oxygen. Proceedings of the National Academy of Science of the United States of America, 89: 1142811430.

Leljak-Levanic D, Bauer N, Mihaljevic S, Jelaska S, 2004. Changes in DNA methylation during somatic embryogenesis in Cucurbita pepo L. Plant Cell Reports, 23: 120-127.

Miyamoto S, Kashiwagi K, Watanabe S, Igarashi K, 1993. Estimation of polyamine distribution and polyamine stimulation of protein synthesis in Escherichia coli. Archives of Biochemistry and Biophysics, 300: 63-68.

Mohammed KB, Ma TH, 1999. Tradescantia-micronucleus and -stamen hair mutation assays on genotoxicity of the gaseous and liquid forms of pesticides. Mutation Research-Fundamental and Molecular Mechanisms of Mutagenesis, 426: 193-199.

\section{CONCLUSION}

The random application of these pesticides has already created a public health hazard. This study suggests that polyamines could be an alternative for reducing genotoxic damage against chemical mutagens in plant. However, more research should be done for understanding the mechanism of the protective effect of polyamines on plants as shown in these experiments.

Oakes DJ, Webster WS, Brown Woodman PDC, Ritchie HE, 2002. Testicular changes induced by chronic exposure to the herbicide formulation, Tordon $75 \mathrm{D} \otimes(2,4$-dichlorophenoxyacetic acid and picloram) in rats. Reproductive Toxicology, 16: 281-289.

Olea-Popelka F, Mclean DM, Horsman J, Almquist K, Bramdle JE, Hall C, 2005. Increasing expression of an anti-picloram singlechain variable fragment $(\mathrm{ScFv})$ antibody and resistance to picloram in transgenic tobacco (Nicotiana tabacum). Journal of Agricultural and Food Chemistry, 53: 6683-6690.

Ruiz-Herrera J, Ruiz-Medrano R, Dominguez A, 1995. Selective inhibition of cytosine DNA methylases by polyamines. FEBS Letters, 357: 192-196.

Salvi ND, George L, Eapen S, 2001. Plant regeneration from leaf base callus of turmeric and random amplified polymorphic DNA analysis of regenerated plants. Plant Cell, Tissue and Organ Culture, 66: 113-119.

Sawamura S, Jackson WT, 1968. Cytological studies in vivo of picloram, pyriclor, trifluralin, 2,3,6-TBA, 2,3,5,6-TBA and nitralin. Cytologia, 33: 545-554.

Sung S, Amasino RM, 2004. Vernalization in Arabidopsis thaliana is mediated by the PHD finger protein VIN3. Nature, 427: 159164.

Taspinar MS, Agar G, Yildirim N, Sunar S, Aksakal O, Bozari S, 2009. Evaluation of selenium effect on cadmium genotoxicity in Vicia faba using RAPD. Journal of Food, Agriculture and Environment, 7: 857-860.

Temel A, Gozukirmizi N, 2013. Analysis of retrotransposition and DNA metyhlation in barley callus culture. Acta Biologica Hungarica, 64: 86-95.

Wang W, Qiao Q, Sun F, Wang Y, Xu D, Li Z, Fu B, 2016. Genomewide differences in DNA methylation changes in two contrasting rice genotypes in response to drought conditions. Frontiers in Plant Science, 7: 1675.

Yildirim N, Agar G, Taspinar MS, Turan M, Aydin M, Arslan E, 2014. Protective role of humic acids against dicamba-induced genotoxicity and DNA methylation in Phaseolus vulgaris L. Acta Agriculturae Scandinavica, Section B - Soil \& Plant Science, 64: 141-148.

Zeid IM, Shedeed ZA, 2006. Response of alfalfa to putrescine treatment under drought stress. Biologia Plantarum, 50: 635-640. 